\title{
CRYOSPHERIC IMPACTS OF SOVIET RIVER
}

\section{DIVERSION SCHEMES}

by

\author{
T. Holt, P. M. Kelly and B. S. G. Cherry
}

(Climatic Research Unit, School of Environmental Sciences, University of East Anglia, Norwich NR4 7TJ, England)

\section{ABST RACT}

Soviet plans to divert water from rivers flowing into the Arctic 0cean have led to research into the impact of a reduction in discharge on Arctic sea ice. We consider the mechanisms by which discharge reductions might affect sea-ice cover and then test various hypotheses related to these mechanisms. We find several large areas over which sea-ice concentration correlates significantly with variations in river discharge, supporting two particular hypotheses. The first hypothes is concerns the area where the initial impacts are likely to which is the Kara Sea. Reduced riverflow is associated occur, with decreased sea-ice concentration in 0ctober, at the time of ice formation. This is believed to be the result of decreased freshening of the surface layer. The second hypothes is concerns possible effects on the large-scale current system of the Arctic Ocean and, in particular, on the inflow of Atlantic and Pacific water. These effects occur as a result of changes in the strength of northward-flowing gradient currents associated with variations in river discharge. Although it is still not certain that substantial transfers of riverflow will take place, it is concluded that the possibility of significant cryospheric effects and, hence, large-scale climate impact should not be neglected.

\section{NT RODUCT ION}

Increasing demands on water resources in the southern USSR have severely reduced the discharges of rivers flowing into the Caspian, Aral and Azov seas. The fall in the levels of these inland seas (caused by riverflow withdrawals and climatic change), coupled with the rapid rate of population growth in the Central Asian republics and the need for improved agricultural production, has forced Soviet planners to search for alternative water supplies. The solution currently favoured involves the transfer of water from the north by diverting part of the flow of rivers discharging into the Arctic Ocean.

Current transfer proposals, which have been discussed in detail by Kelly and others (1983), involve the withdrawal of up to $25 \mathrm{~km}^{3} \mathrm{a}^{-1}$ from the Severnaya Dvina and Pechora rivers (see Figure 1 for geographical locations) commencing around 1990. Up to $60 \mathrm{~km}^{3} \mathrm{a}^{-1}$ may be withdrawn from the river $0 b^{\prime}$ with in the following 15 to 30 a and th is could be augmented by at least $100 \mathrm{~km}^{3} \mathrm{a}^{-1}$ from the river Yenisey during the twentyfirst century. The consequences of the withdrawals could be far-reaching as the discharge plays an important role in maintaining the steady-state characteristics of the Arctic ice cover. A substantial change in the ice cover could have widespread climatic repercussions. We attempt to evaluate this risk by testing some of the theories discussed by Micklin (1981) concerning the cryospheric impact of reductions in riverflow. Sea-ice concentration data for the Arctic and its marginal seas are correlated with flow data for major Siberian rivers. The mechanisms examined are summarized in Table I and described in detail in the next section.

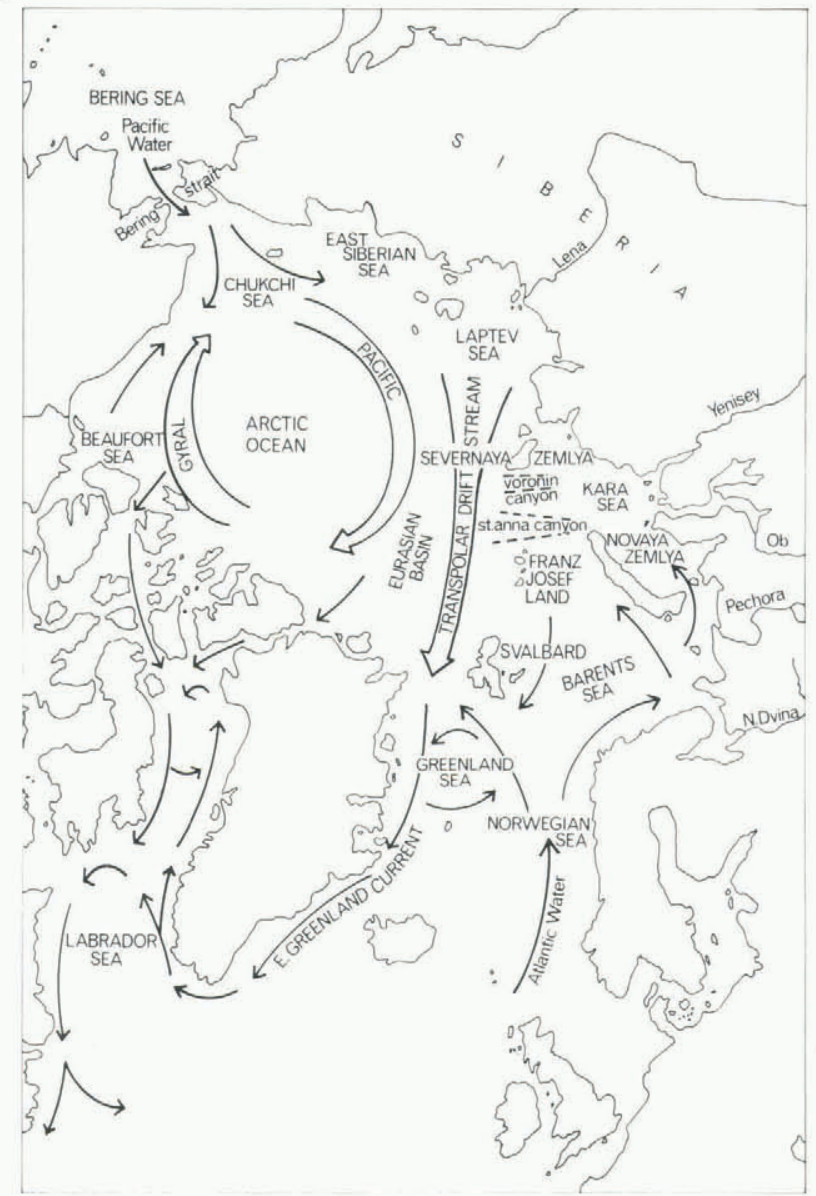

Fig.1. Geographical locations, surface currents (single arrows) and principal ice-drift currents of the Arctic Basin (double arrows). (After Häggblom 1982.) 
TABLE I. MECHANISMS BY WHICH RIVER DIVERSIONS MIGHT AFFECT SEA-ICE COVER

\begin{tabular}{|c|c|c|c|c|c|}
\hline \multicolumn{2}{|c|}{$\begin{array}{l}\text { Proposed effect of } \\
\text { discharge reduction }\end{array}$} & \multirow{2}{*}{$\begin{array}{l}\text { Effect on } \\
\text { sea ice }\end{array}$} & \multirow{2}{*}{$\begin{array}{l}\text { Seasons } \\
\text { Spring }\end{array}$} & \multirow{2}{*}{$\begin{array}{l}\text { Area } \\
\text { Estuaries } \\
\text { and } \\
\text { deltas }\end{array}$} & \multirow{2}{*}{$\begin{array}{l}\text { References } \\
\begin{array}{l}\text { Antonov } 1976 \\
\text { Lupachev } 1979\end{array}\end{array}$} \\
\hline I & $\begin{array}{l}\text { Delay, in fast-ice } \\
\text { break-up }\end{array}$ & & & & \\
\hline II & $\begin{array}{l}\text { Decreased heat } \\
\text { content of } \\
\text { surface water }\end{array}$ & Increase & $\begin{array}{l}\text { Summer } \\
\text { /autumn }\end{array}$ & $\begin{array}{l}\text { Offshore } \\
\text { at river } \\
\text { mouths }\end{array}$ & $\begin{array}{l}\text { Antonov } 1976 \\
\text { Lupachev } 1979\end{array}$ \\
\hline I I I & $\begin{array}{l}\text { Reduced } \\
\text { freshening }\end{array}$ & Decrease & $\begin{array}{l}\text { Autumn } \\
\text { /winter }\end{array}$ & $\begin{array}{l}\text { Shelf } \\
\text { seas }\end{array}$ & Antonov 1976 \\
\hline IV & $\begin{array}{l}\text { Reduced thickness } \\
\text { of pycnocl ine, } \\
\text { hence, increased } \\
\text { heat release to } \\
\text { the surface }\end{array}$ & Decrease & & $\begin{array}{l}\text { Eurasian } \\
\text { Bas in }\end{array}$ & $\begin{array}{l}\text { Aagaard and } \\
\text { others } 1981\end{array}$ \\
\hline v & $\begin{array}{l}\text { Weaker gradient } \\
\text { currents in shelf } \\
\text { seas reducing } \\
\text { strength of warm } \\
\text { inflow from } \\
\text { southern oceans }\end{array}$ & Increase & & $\begin{array}{l}\text { Where ice- } \\
\text { cover is } \\
\text { affected } \\
\text { by influx } \\
\text { of warm } \\
\text { water }\end{array}$ & $\begin{array}{l}\text { Antonov } 1976 \\
\text { Nik iforov and } \\
\text { others } 1980\end{array}$ \\
\hline
\end{tabular}

\section{MECHANISMS}

The first three mechanisms that we consider involve relatively localized impacts. According to Antonov (1976), the warm riverflow promotes the breakup and removal of fast ice in the estuary and delta regions of the rivers. A reduction in riverflow could lead to delayed removal of fast ice from these areas in spring, as there would be less heat available for ice-melt, and to a reduction in the rate of removal of broken fast ice (mechanism I). Riverflow also increases the heat content of offshore waters in summer (Antonov 1976). A reduction in the heat flow could slow the rate of ice-melt around the river mouths in summer and, possibly, promote early fast-ice formation in these areas in autumn (mechanism II). Some evidence for these effects has been presented by Lupachev (1979) and by Potanin and Dement'yev (1982) who considered withdrawals from the Severnaya Dvina and Pechora. Finally, as far as local impacts are concerned, the freshening effect of riverflow facilitates the formation of new ice in autumn in the river mouths and offshore, creating favourable conditions for the rapid growth and spread of fast ice in winter (Antonov 1976). I ce grows more rapidly in less saline water, so a reduction in discharge could lead to reduced or delayed ice formation in autumn (mechanism III).

Mechanism IV is concerned with larger-scale effects. The pronounced cold halocline (salinity gradient) between 50 and $200 \mathrm{~m}$ and the thick layer of warm, highsalinity water of Atlantic origin centred between 300 to $500 \mathrm{~m}$ are major hydrographic features of the Arctic ocean. On entering the Arctic Ocean (to the west of Svalbard, between Zemlya Frantsa-Ios ifa and Novaya Zemlya, and through the straits at the southern tip of Novaya Zemlya), the Atlantic inflow sinks below the less dense polar surface water (see Fig.1). At low temperatures, the dependence of density on salinity is relatively large compared with the dependence on temperature. Therefore, the halocl ine is also a marked pycnocline (density gradient) which suppresses upward heat flow from the deep Atlantic water to the surface and forms a dynamic barrier to convection driven by freezing and cooling at the surface (Aagaard and Coachman 1975). The sources of the cold, saline water that maintains the pycnocline against surface outflow in the East Greenland Current are not firmly estab1 ished. Nonetheless, a reduction in riverflow will certainly lead to increased salinity in the Siberian shelf seas and this could cause the shelf water to sink below the pycnocline when it enters the Arctic Basin. Aagaard and others (1981) suggest that the subsequent thinning of the pycnocl ine would make the Atlantic layer more susceptible to direct surface cooling. Thus, a reduction in river discharge could lead to warmer, more saline surface water in the central Arctic as the convective currents set up by the deep-sinking shelf water allow heat from deep Atlantic water to reach the surface. Taking an extreme example, Aagaard and Coachman (1975) suggested that total withdrawal of the flow of the $0 b^{\prime}$ and Yenisey could lead to the removal of much of the pycnocline over the Eurasian Basin with in 2 to 3 years, making about $10^{6} \mathrm{~km}^{3}$ of ocean free of ice for prolonged periods.

As this hypothes is relates to ice cover in areas of the Arctic 0cean where there is almost no seasonal variation in sea-ice concentration, it is impossible to test it with the data used in this particular analysis. While a limited amount of suitable data may be available for some areas for use in empirical investigations of this mechanism, probably the only way to examine the hypothes is successfully is with the aid of numerical models.

Mechanism V concerns effects on Arctic ocean currents and, in particular, the possible impact on the flow of warm Atlantic and Pacific waters into the Arctic Ocean and the subsequent circulation of this water. We first consider the formation of gradient currents in the marginal seas.

Fresh water from the rivers is concentrated in the eastern parts of the Kara and Laptev seas, with highsalinity Atlantic water entering the western parts. The difference in geopotential associated with the density gradient between these water masses determines the strength of northward-flowing gradient currents. These result from geostrophic balance between the easterly component of the geopotential gradient in these seas and the Coriolis force. The gradient currents are described by Antonov (1958) as influencing the major outflow from the Arctic Ocean, i.e. the Transpolar Drift Stream leading to the East Greenland 
Current. Nikiforov and others (1980) estimated that the geopotential difference in the Kara and Laptev seas can reach 0.04 dynamic metres ( 1 dynamic metre $=$ $10 \mathrm{~J} \mathrm{~kg}^{-1}$ ) in summer, giving an additional and significant component to current speeds of about $2.5 \mathrm{~cm} \mathrm{~s}^{-1}$. (Unfortunately, full details of their calculations are not given. Two previous attempts at similar calculations (Garcia 1969, Hanzlick and Aagaard 1980) failed because of problems in establishing a valid reference level.) Reduction in river discharge, leading to weakening of the gradient currents and outflow from the shelf seas, could produce decreased flow in the Transpolar Drift Stream and the East Greenland Current. Decreased outflow from the shelf seas could have mare local effects. Several Soviet studies (for example, I vanov and Nik iforov 1976, Nik iforov and others 1980) assert that there is a direct link between the rate of surface outflow from the Kara Sea and the rate of inflow into the Kara Sea of deep Atlantic water from the Barents Sea and through the Voronin and St Anna canyons. It is not clear how much the Soviet conclusions owe to direct observations of currents and how much to intuitive deductions based on water continuity and/or inferences from temperature and salinity data. Nevertheless, there is some support for this process. Coachman and Barnes (1962) suggested that an estuarine circulation exists in the shelf seas. For example, in the Kara Sea the surface flow off the continental shelf could drive the inflow of deep Atlantic water upwards along the St Anna and Voronin canyons. The resulting upwell ing and mixing would explain the paradox of the highest-salinity surface water occurring along the edge of the Eurasian continental shelf and the northern Barents, Kara and Laptev seas (areas entraining the greatest volume of fresh water from continental flow). Using salinity and temperature data collected in 1965 by the USCGC Northwind survey of the Kara Sea, Hanzlick and Aagaard (1980) provided 1 imited support for the estuarine circulation model. A reduction in riverflow, with the associated reduction in the speed of northward-flowing gradient currents, could then lead to reduced inflow of warm, saline, deep Atlantic water into the Kara and Laptev seas, assuming a similar mechanism operates in both areas. It has been calculated that increased ice cover, particularly in the spring and autumn transition periods, would result from the reduction in the transfer of heat and salt to the surface from the deep Atlantic water (Ivanov and Nikiforov 1976).

Recently, two modelling exercises have addressed the question of impacts of riverflow diversions. Stigebrandt (1981) examined the relationship between ice thickness and external parameters such as freshwater input. He concluded that, even if the total fresh-water input to the Arctic Ocean were reduced by $50 \%$ (far more than any proposed diversions), there would only be a minimal effect on ice thickness and extent in the Arctic 0cean. He did note, however, that the effects would be magnified if other factors, such as the amount of warm Pacific and Atlantic water entering the Arctic, also changed. Semtner (in press) found that, for partial or total withdrawal of the discharge into the Kara and Barents seas, there was almost no effect on the pycnocline in the central Arctic Ocean. Also, although the vertical stability in the two shelf seas was greatly reduced in the case of total diversion, there was no notable increase in convective overturning and the ice extent remained virtually unchanged.

\section{DATA AND METHODOLOGY}

A number of theories concerning the cryospheric impact of reductions in fresh-water discharge have been described. Some favour increased ice extent and/or thickness as a result and others favour a decrease. The purpose of this study is to use empirical methods to test the relationships between riverflow and ice cover suggested above. The specific hypotheses under investigation concern the effects of flow reductions on ice break-up, advection and formation close to the river mouths and larger-scale impacts arising through changes in the strength of the gradient currents in the Siberian shelf seas. For the reasons mentioned earlier, we are unable to consider the pycnocline mechanism (mechanism IV). Most mechanisms can be associated with a preferred time of year and area in which their effects are likely to be most pronounced (Table I).

To test these hypotheses, we have correlated the discharges of the Lena, $O \mathrm{~b}^{\prime}$ and Yenisey rivers with data on sea-ice concentration. The river Lena, al though not involved in any diversion scheme, is included for comparative purposes as it makes a considerable contribution to the fresh-water input to the Arctic 0cean. The smaller rivers involved in diversion schemes, the Severnaya Dvina and Pechora, are not considered here.

The sea-ice data were extracted from Walsh's (1979) set of concentration in tenths for the period 1953 to 1977. Monthly values are used covering the whole of the Arctic 0cean and the adjacent seas at a spatial resolution of about $100 \mathrm{~km}$. The riverflow data (from UNESCO 1966 to 1979) are monthly mean discharges $\left(\mathrm{m}^{3} \mathrm{~s}^{-1}\right)$ for the $O \mathrm{~b}^{1}$, Yenisey, and Lena rivers (1953 to 1977). To simpl ify comparison with the proposed diversions, the discharges have been converted to $\mathrm{km}^{3}$. We use the total annual flow for the hydrological year, October to September, as a discharge index for each river. Annual riverflow data were correlated with monthly sea-ice concentration data for the 18-month period from the April of the current hydrological year through to September of the following year. The correlations can obviously only be undertaken for the regions where sea-ice concentration varies from year to year and these regions change from month to month as the ice advances and retreats (see, for example, Figures 5 and 6). All significance tests are at the 5\% level and allowance is made for autocorrelation when appropriate (Quenouille 1952).

Before describing our results, we 1 ist various drawbacks of our analysis. These mostly arise from 1 imitations in the available data. The distribution of water masses in the Siberian peripheral seas, as described by Shpaykher and others (1972), suggests that the spatial resolution of our data (about $100 \mathrm{~km}$ ) may not be sufficient to define certain of the smallerscale relationships. For example, the warming influence of the river water probably extends only about 100 to $200 \mathrm{~km}$ out to sea. Moreover, the identification of relationships between discharge and ice formation in the estuaries and mouths of the rivers could well require greater temporal resolution than one month as they freeze up rapidly between September and October. The geography of river discharge is another complicating factor. Part of the discharge of the Yenisey, for example, flows into that of the $0 b^{\prime}$, and local effects from the Lena could be masked by the division of its flow by the extensive delta system. Finally, lack of data precludes investigation of effects on ice thickness, such as suggested by mechanism IV, al though these may be as important as effects on ice concentration or extent.

It should also be noted that between 80 and $85 \%$ of the total annual discharge of the rivers considered occurs from May to September. The major contributions to flow in this period are the spring snow-melt, giving the maximum flow in June, and the summer precipitation regimes over the river catchments. The summer precipitation maxima usually occur in July and August (and in September close to the Kara Sea). The effects of these individual components of the fiow regimes have not been considered but may be different and/or clearer than the effects of the total flow, examined in this analysis.

\section{RESULTS}

The total annual discharge of each river is significantly correlated with sea ice over much of the Arctic Basin. Significant correlations occur at lags of up to ten months and, with allowance for seasonal 
movement of the ice margin, the patterns are frequently geographically consistent from one month to the next over periods of up to six months. The areas of significant correlation are mapped in Figures 2, 3 and 4. Significant correlations occurring in grid squares that are isolated in space and/or time have been omitted. Figures 5 and 6 show the position of the zero and total ice limits in particular months for a sub-set of the correlation patterns, some of which also illustrate the consistency in time of the correlations and their seasonal progression with the ice margin.

Owing to the large number of correlations undertaken, it is certain that some significant correlations will arise by chance. We, therefore, restrict our initial discussion to those significant correlations occurring in the areas and at the times of year relevant to the hypotheses 1 isted in Table I. The experiment is expressed as a classical hypothes is test and the null hypothes is of no significant impact accepted in the absence of significant correlations in any of the preferred regions and/or seasons. We then speculate about the causes of the other significant correlations, bearing in mind the possibility that they might

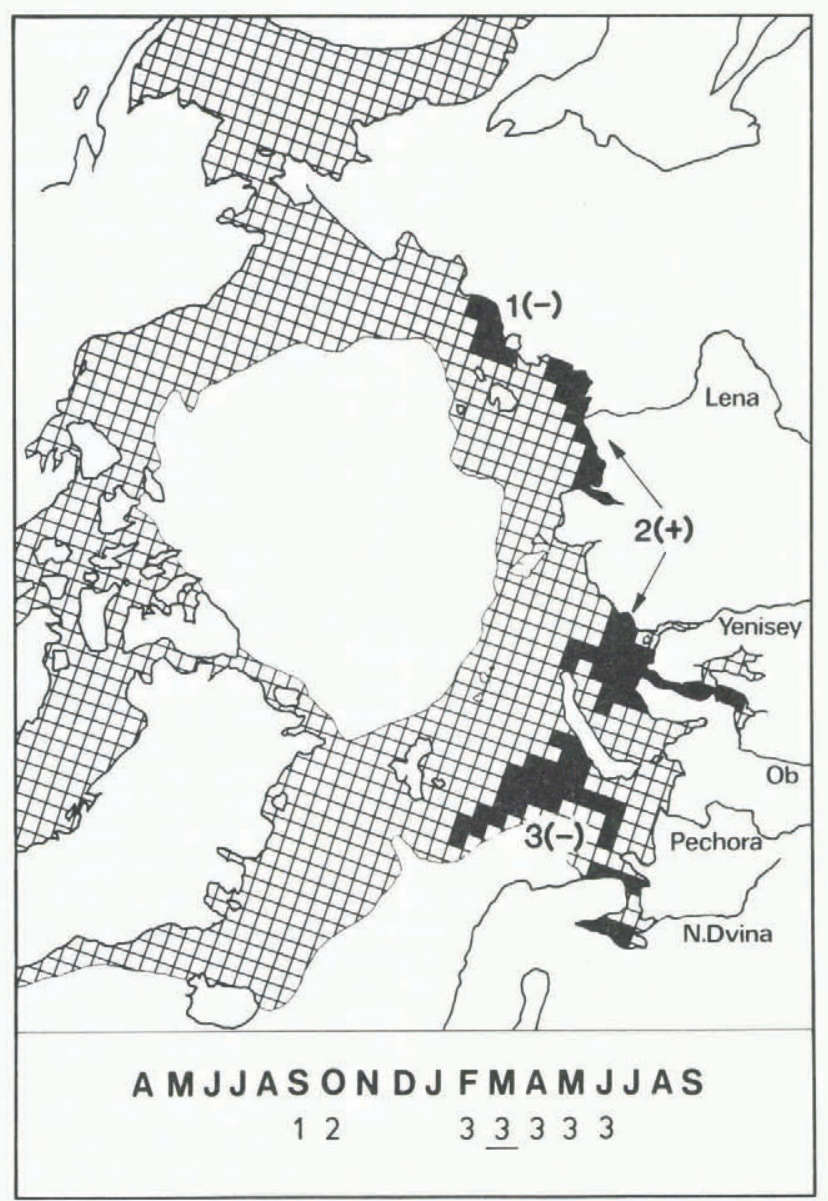

Fig.2. Major areas of significant correlation between the annual flow of the river $0 b^{\prime}$ and monthly sea-ice concentration. (Key: The sign of each correlation is shown next to the shaded area on the map. The number next to the sign refers to the table of months below the map, and is used to indicate the month in which a particular correlation pattern occurred with respect to the current hydrological year. Where a pattern persists for more than one month, the pattern shown occurred in the month with the underlined reference number. The table of months begins in April of the current hydrological year. The grid squares show the maximum extent of variable ice cover throughout the year (1953 to 1977).)

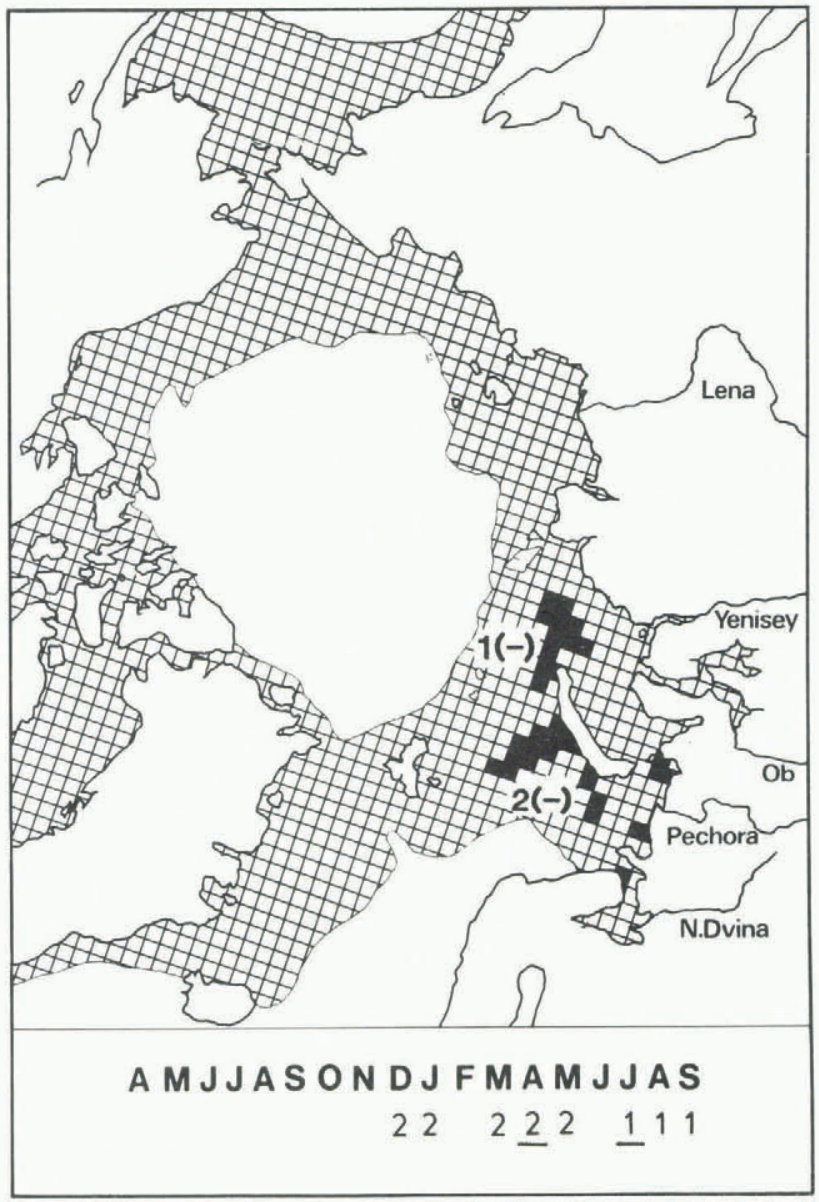

Fig.3. Major areas of significant correlation between the annual flow of the river Yenisey and monthly sea-ice concentration. (For explanation of key, see Figure 2.)

be spurious, arising by chance in the large sample of correlation undertaken, or caused by some third factor forcing both riverflow and sea-ice extent.

Effect on spring break-up (mechanism I) and summer ice conditions (mechanism II)

No notable correlations occur near the river mouths in spring or offshore in summer and we accept the null hypotheses that these mechanisms have no significant effect. The only qualifications that we attach to this conclusion concern the spatial and temporal resolution of our data, as discussed above.

\section{Effect on autumn ice formation (mechanism III)}

There is a significant positive relationship between the flow of the river $0 b^{\prime}$ and the sea-ice concentration during October in the south-eastern Kara Sea (Figs.2 and 6(d)). This supports the hypothes is that variations in riverflow affect the freshening of the shelf seas and, hence, autumnal ice formation. The correlations cover virtually the same area as that defined by Hanzlick and Aagaard (1980) as enclosing an "above-normal equivalent thickness of fresh water", providing independent qual itative support for the freshening hypothesis. Reduced riverflow is associated with delayed ice formation in October (decreased ice extent) over the central Kara Sea and Obskaya Guba.

We note that mechanism $V$, if valid, suggests that decreased riverflow will have the opposite effect over much of this area, as the deep Atlantic inflow is weakened resulting in less heat transfer to the surface and greater ice formation (T imofeyev 1962). The fact that this relationship is not observed indicates that 


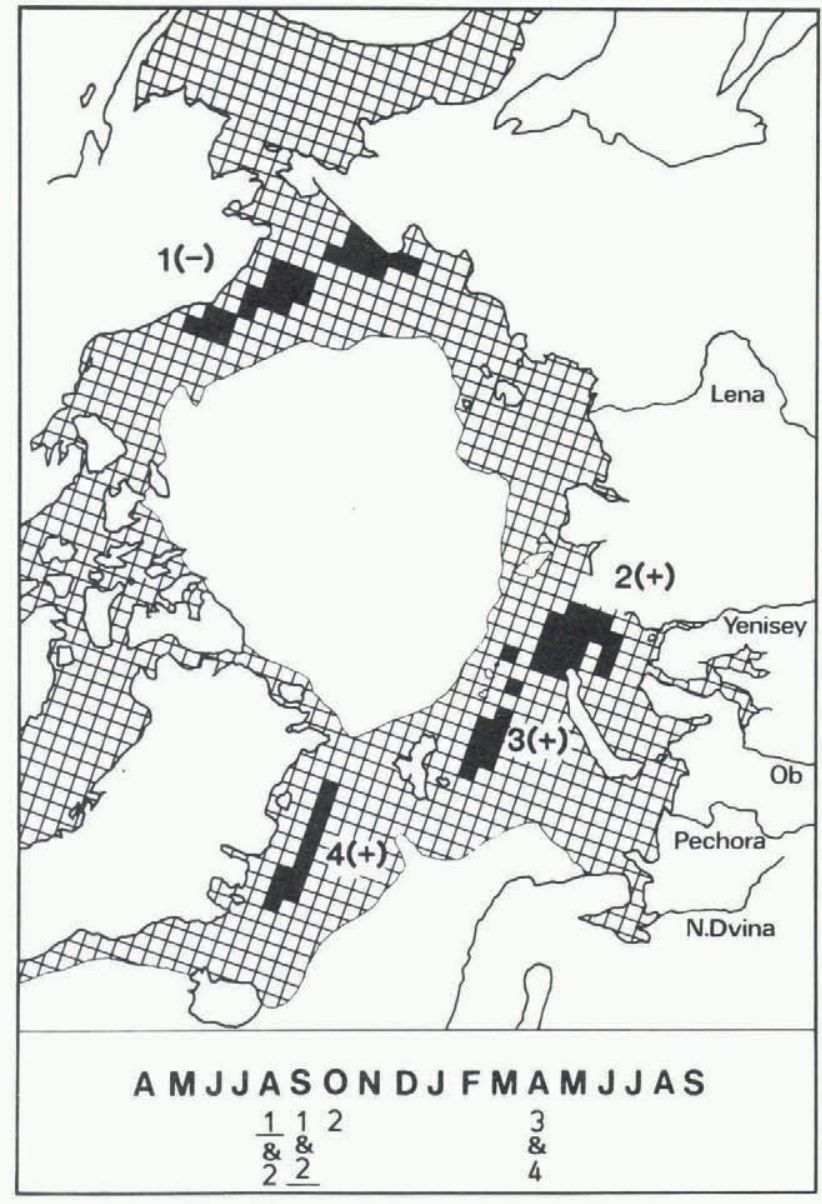

Fig.4. Major areas of significant correlation between the annual flow of the river Lena and monthly seaice concentration. (For explanation of key, see Figure 2.)

this mechanism is not as important as the freshening effect in the october immediately following the current hydrological year and/or that its impact takes longer to develop. In fact, as discussed later, low riverflow is followed by increased ice formation in the following year.

No major areas of significant correlation occur in the Yenisey and Lena analyses at this time of year (Figs.3 and 4 ). We have noted above that the gauged flow on these rivers may not be a good index for use in studies of local, direct effects on sea-ice conditions.

\section{Effects on the large-scale ocean circulation}

\section{Tmechanism V}

One would expect to find evidence of this mechanism in those areas where the gradient currents are strongest (the Kara and Laptev seas) and where the in flow from the Atlantic and Pacific is known to influence sea-ice conditions directly. This could be either by heat release from below (over the canyons at the mouths of the Kara and Laptev seas) or by advection of ice and warm water at the surface (in the Barents and Chukchi seas). Increased sea-ice concentration in these areas, produced by weakened Atlantic or Pacific inflow, should be associated with reduced riverflow.

Sea-ice concentration in the Barents Sea is negatively correlated with the flow of the $0 b^{\prime}$ from February to July (Fig. 2), and with the flow of the Yenisey during December and January and March to May (Figs.3 and 5), of the following hydrological year. These are notable sequences of spatially-coherent correlations. The strongest correlations occur during March or April, the time of maximum ice extent. We suggest that these results validate mechanism $V$. Increased sea-ice concentration associated with riverflow reductions in the previous year is caused by reduced advection and melt-: ing by weakened inflow of Atlantic water at the surface. The reduced inflow of Atlantic water is a response to the weakened gradient currents in the Kara Sea. The patterns of significant correlation agree well with the flow patterns of the Atlantic water in the Barents Sea. Interestingly, the correlations with $0 b^{\prime}$ riverflow are generally located in the vicinity of the south-east branch of the Atlantic inflow, whereas the Yenisey correlations are located west of Novaya Zemlya (Fig.5).

The significant negative correlations between the flow of the river Lena and sea-ice concentration in the Chukchi Sea during August and September (Figs.4 and $6(c))$, towards the end of the open-water season, suggest that a reduction in the strength of the Pacific inflow takes place when the flow of the Lena is reduced. As in the Barents Sea, these correlations affect the areas where the warm surface inflow is strongest. It is suggested that the reduction in the Laptev Sea gradient current following a reduction in riverflow lowers the rate of flow of the Transpolar Drift Stream. This results in increased sea-level north of the Bering Strait which reduces the surface inflow from the Pacific (Coachman and Aagaard 1966).

\section{DISCUSSION}

We have presented evidence which suggests that there is a strong link between the flow of the major Siberian rivers and the character of the current system of the Arctic Ocean, including the strength of the Atlantic and Pacific inflows. In this section, we elaborate on this hypothes is through the interpretation of certain of the correlations whose relevance to the

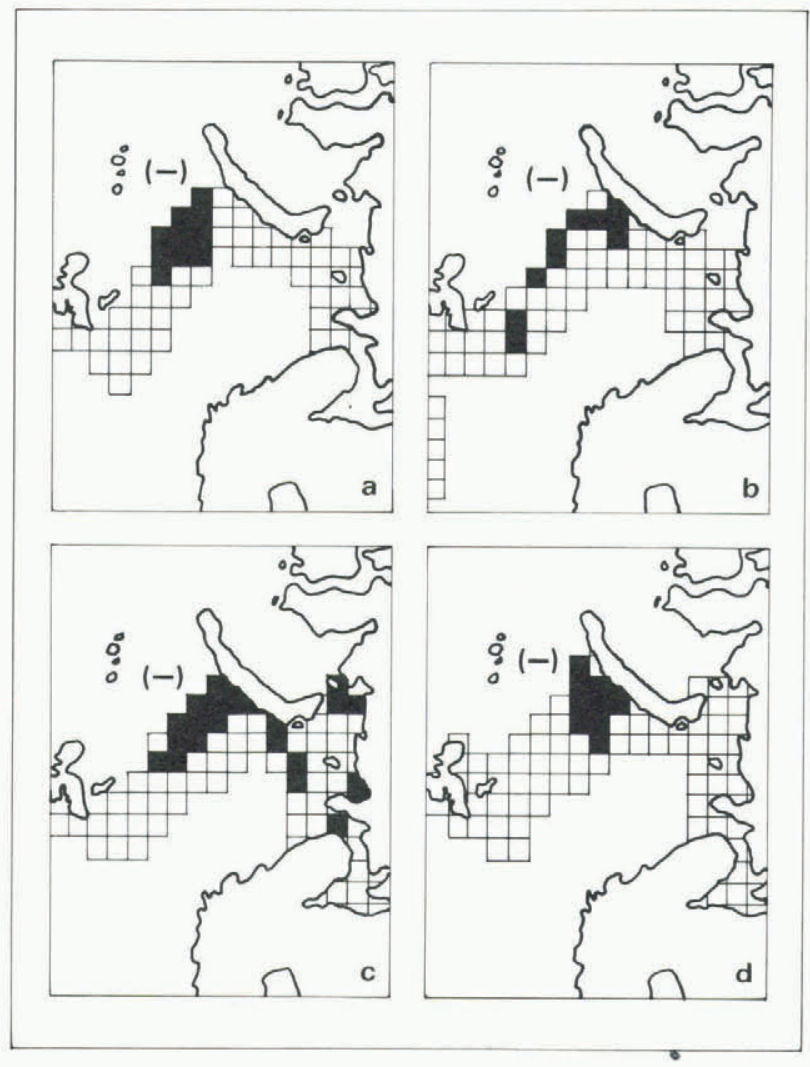

Fig.5. Areas of significant correlation (-) between the annual flow of the river Yenisey and sea-ice concentration in the Barents Sea in the following year. The grid squares show the extent of variable ice cover in the given month. (Key: (a) January ice, (b) March ice, (c) April ice, (d) May ice.) 


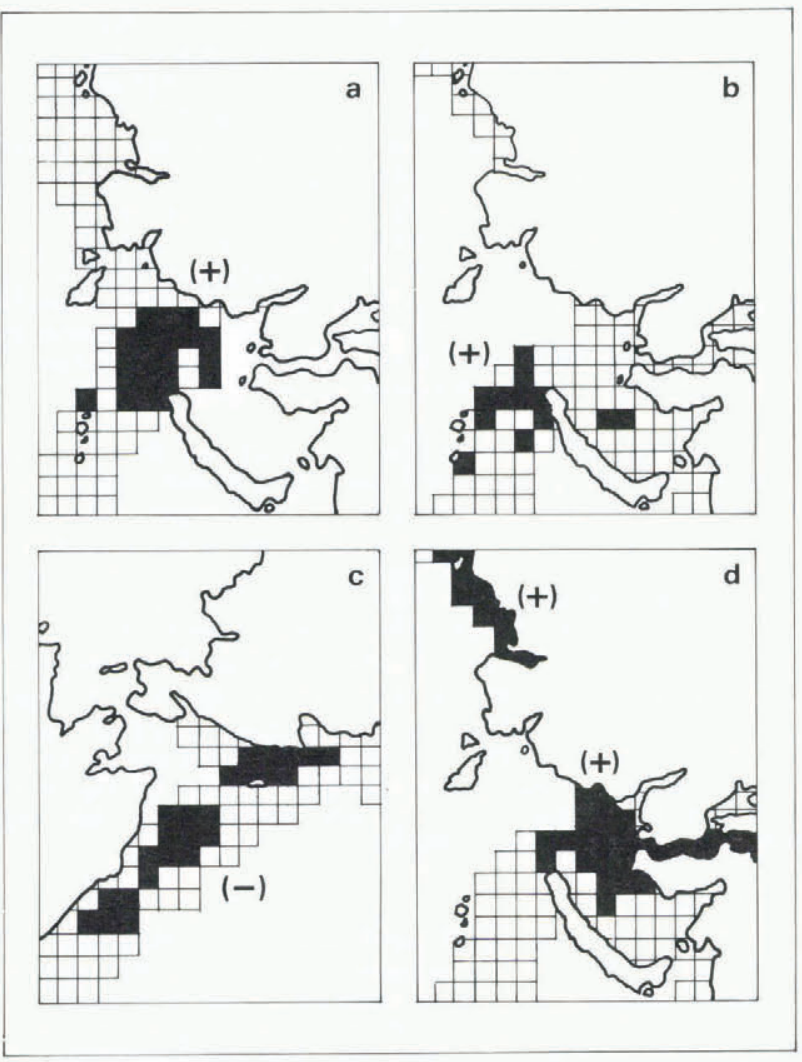

Fig.6. (a) and (b): significant correlations (+) between the annual flow of the river Lena and sea-ice concentration in the Kara Sea in the current September and following 0ctober, respectively. The grid squares show the extent of variable ice in the given month. (c): significant correlations $(-)$ between the annual flow of the river Lena and sea-ice concentration in the Chukchi Sea in the current August. (d): significant correlations $(+)$ between the annual flow of the river $O \mathrm{~b}^{\prime}$ and sea-ice concentration in the Kara Sea in October following the current hydrological year.

mechanisms 1 isted in Table $\mathrm{I}$ is not immediately obvious. They represent aspects of the mechanisms which were not drawn out by previous investigators. A clear distinction is to be drawn between this discussion which is, of necessity, somewhat speculative and the previous rigorous hypothes is tests.

The positive correlation of the flow of the Lena with sea-ice concentration in the Kara Sea from August to October of the current hydrological year (Figs.4 and $6(a)$ and (b)) could be the result of an estuarine circulation in the Laptev Sea similar to that proposed by Coachman and Barnes (1962) for the Kara Sea. Increased riverflow would be associated with increased deep Atlantic inflow from the Arctic Bas in to the Laptev Sea. This could then lead to a reduction in the amount of Atlantic water entering the Voronin and St Anna canyons as the main flow of deep Atlantic water along the continental shelf increases to the east. A reduction in the amount of Atlantic water entering the canyons implies reduced heat release to the surface through mixing in the central Kara Sea and, consequently, less ice melt in summer, resulting in the positive correlation between the flow of the Lena and sea-ice concentration in this region.

The Yenisey flow correlates negatively with seaice concentration in the northern Kara Sea during the period July to September following the current hydrological year (Fig.3). The August and September correlations are less spatially coherent and located progressively closer to Severnaya Zemlya. These could be related to changes in the eastward progression of
Atlantic water from the Barents Sea to the Kara Sea as a result of changes in the flow of Atlantic water into the Barents Sea earlier in the year. A connection between reduced riverflow and weakened Atlantic inflow in the Barents Sea in the following late winter, spring and early summer has been demonstrated above (Figs. 3 and 5). A logical consequence of this would be a weakening of the flow of Atlantic water from the Barents Sea to the Kara Sea, resulting in less heat release and summer ice-melt in progressively more easterly locations. Similar, more confined patterns are found in the $O \mathrm{~b}^{\prime}$ analysis, but situated in the south-western and central Kara Sea. This suggests that the discharge of the $O b^{\prime}$ influences the flow of Atlantic water from the Barents Sea.through the strait at the southern tip of Novaya Zemlya. This hypothes is is supported by the location of the major correlations between the flow of the $0 b^{\prime}$ and sea-ice concentration in the south-eastern Barents Sea earlier in the year.

The significant positive correlations between $0 b^{\prime}$ discharge and sea-ice concentration in 0ctober in the Laptev Sea following the current hydrological year (Figs.2 and $6(d)$ ) could be the result of changes in the fresh-water transport from the Kara Sea to the Laptev Sea (Shpaykher and Fedorova 1976). A reduction in riverflow, leading to reduced fresh-water transport, could encourage reduced ice-formation because of the increased salinity of the shelf waters in the Laptev Sea, as occurs in the Kara Sea at this time of year.

The significant correlations between the flow of the Lena and sea-ice concentration in August following the current hydrological year in the Barents and Greenland seas (Fig.4) and between the flow of the $0 b^{\prime}$ and sea-ice concentration during the current September in the East Siberian Sea (Fig.2) have no obvious explanation and can be dismissed as spurious given the large number of correlations undertaken. If indicative of genuine physical processes, it is reasonable to expect a degree of continuity between adjacent months and this does not occur in these cases.

\section{CONCLUSIONS}

We have described various hypotheses relating reductions in the discharge of northward-flowing Soviet rivers to changes in Arctic sea-ice cover. These have been tested by correlating annual riverflow with seaice concentration over the Arctic 0cean and its marginal seas at lags of up to 15 months. Our results indicate that large areas of sea ice, several hundred kilometres from the river mouth, can be affected by variations in riverflow. The most immediate impact of riverflow reductions is seen in the Kara Sea in the autumn following low flow of the $0 b^{\prime}$ when decreased sea-ice extent occurs, most likely owing to reduced freshening of the surface layer. There is no evidence, however, of any other effect on sea-ice conditions in the mouths and estuaries of the rivers. This failure to find significant local relationships could be due to the low spatial and temporal resolution of the data.

The large-scale patterns of significant correlations show that a reduction in river discharge is associated with increased ice in some areas and reduced ice in others. Because of the lack of data, particularly time series of ocean-current strength, the interpretation of certain of the relationships is somewhat speculative. Nevertheless, it does appear that reduced riverflow is related to weakening of the major currents of the Arctic 0cean and, in particular, the circulation of the inflow from the Atlantic and Pacific sectors. The suggested link between these currents and riverflow is the northward-flowing gradient currents in the Kara and Laptev seas. These are formed as a result of the density gradient between fresh water in the eastern part of the seas and high-salinity Atlantic water in the west. The correlations indicate that diversions from the $0 b^{\prime}$ and Yenisey will be followed by extensive increases in ice cover in the Barents Sea throughout much of the period from late winter to early summer. From July to September, our results suggest that 
there could also be increased ice in the central and eastern Kara Sea as the effects of the reduced inflow of Atlantic water from the Barents Sea to the Kara Sea penetrate eastwards.

We conclude that diversions comparable in magnitude to the natural variations considered here will noticeably affect Arctic ice cover. Such diversions may take place during the early decades of the twenty-first century, although no decision on implementation of the transfers in the Siberian sector has yet been made. Implementation of the European scheme is proceeding (Kelly and others 1983) and Soviet scientists are now investigating the potential risks of the much larger Siberian scheme (Nikiforov and others 1980). The impact of permanent, anthropogenic reductions in riverflow may be somewhat different from the effects of the transient, natural variations considered here, bat our analys is provides a guide to the most probable effects of the initial transfers

Caution is advisable in the interpretation of our results. This is not only because of the dangers of over-interpretation in a statistical analys is such as this, but also because few data are available to test the precise details of the proposed linkages, particularly those involving changes in ocean currents. Moreover, analys is of the relationships between other $\mathrm{cli-}$ matic parameters, such as air temperature, and sea-ice concentration and riverflow is necessary in order to factor out "external" effects. Such an analys is may also reveal whether or not feedback between the ocean, ice cover and atmosphere plays a part in producing the relationships that we have observed.

As environmental data are lacking, numerical models are needed to study the detailed impact of river flow variations on sea-ice conditions. Empirical studies such as reported here can provide invaluable guidelines concerning the formulation of these models and we suggest that previous modelling efforts have neglected various important factors. For example, it is clear that realistic models must incorporate the seasonal cycles of sea-ice build-up and decay and, possibly, of river discharge. Most of the significant impacts identified above occur in the shelf seas, and a multi-layer ocean with realistic bathymetry is needed if these effects are to be modelled successfully. Given their current state of development, it is unl ikely that numerical models will be able to predict the effects of anything but unrealistically large diversions in the near future. Our approach represents, at present, the only means of evaluating the likely consequences of the first, relatively minor diversions.

\section{ACKNOWLEDGEMENTS}

T Holt holds a Natural Environment Research Council Research Studentship. This research was partially supported by US Office of Naval Research Grant N00014-77-G-0074. We thank our colleagues in the $\mathrm{Cl}$ imatic Research Unit, two anonymous referees, and various participants at the International Glaciological Society Symposium on Ice and Climate Modelling for their comments on this paper.

\section{REFERENCES}

Aagaard K, Coachman L K 1975 Toward an ice-free Arctic Ocean. Eos. Transactions, American Geophysical Union 56(7): 484-486

Aagaard K, Coachman L K, Carmack E 1981 on the halocline of the Arctic Ocean. Deep Sea Research 28(6a): 529-545

Antonov V S 1958 Rol' materikovogo stoka v rezhime techeniye Severnogo Ledovitogo okeana [The role of continental flow with in the regime of Arctic Ocean current]. Problemy Severa 1: 52-64

Antonov V S 1976 K probleme bezvozvratnogo iz"yatiya chasti stoka severnykh rek. Trudy Arkticheskogo $i$ Antarkticheskogo Nauchno-Issledovatel'skogo Instituta 323: 156-167 [English translation: The possible impact on the Arctic Ocean of the proposed transfer of water from the northern rivers of the USSR to the south. Polar Geography 2(4) 1978: 223-231]

Coachman L K, Aagaard K 1966 On the water exchange through Bering Strait. Limnology and oceanography 11(1): 44-59

Coachman L K, Barnes C A 1962 Surface water in the Eurasian basin of the Arctic Ocean. Arctic 15(4): 251-277

Garcia A W 1969 Oceanographic observations in the Kara and eastern Barents seas. US Coast Guard. oceanographic Report 25

Häggblom A 1982 Driftwood in Svalbard as an indicator of sea ice conditions; a preliminary report. Geografiska Annaler 64A(1-2): 81-94

Hanzlick D, Aagaard K 1980 Freshwater and Atlantic water in the Kara Sea. Journal of Geophysical Research 85(C9): 4937-4942

Ivanov V V, Nikiforov E G 1976 Puti otsenki vozmozhnykh izmeneniy gidrologicheskogo rezhima Karskogo morya pod vi iyaniyem mezhbasseynovoy perebroski stoka rek [Ways of estimating possible changes in the hydrological regime of the Kara Sea under the influence of inter-bas in riverflow transfers]. Trudy Arkticheskogo $i$ Antarkticheskogo Nauchno-Issledovatel'skogo Instituta 314: 176-182

Kelly P M, Campbell D A, Mickl in P P, Tarrant J R 1983 Large-scale water transfers in the USSR. GeoJournal 7(3): 201-214

Lupachev Yu V 1979 Gidrologichesk iye usloviya ust'yevoy oblasti Pechory $i$ ikh vozmozhnyye izmeneniya pri iz"yatii chasti stoka iz basseyna. Trudy Gosudarstvennogo Okeanograficheskogo Instituta 143: 49-68 [Engl ish translation: Hydrological conditions of the mouth area or the Pechora and their possible changes after withdrawal of part of the runoff from the basin. Soviet Hydrology: Selected Papers 19(2), 1980: 94-102]

Mick I in P P 1981 A preliminary systems analys is of impacts of proposed Soviet river diversions on Arctic sea ice. Eos. Transactions, American Geophysical Union 62(19): 489-493

Nik if orov Ye G, Moretsk iy V N, Shpaykher A O 1980 Izmenchivost gidrologicheskogo rezhima Severnogo Ledovitogo okeana $i$ problemy, voznikayushchiye $v$ svyazi s perebroskoy chasti stoka rek yego basseyna [The variability of the hydrological regime in the Arctic Ocean and problems associated with the transfer of part of the flow of the rivers of its basins]. Problemy Arktiki i Antarktiki 55: 67-78

Potanin VA, Dement'yev A A 1982 Osnovnyye rezul'taty issledovaniy vozmozhnykh izmeneniy gidrometeorologicheskikh usloviy severnykh morey pod vliyaniyem vodokhozyaystvennykh meropriyatiy [The principal results of research into possible changes in the hydrometeorological conditions of the northern seas due to the effects of water management schemes]. In Tolstikov Ye I, Kornilov N A (eds) Issledovaniya Arktiki, Antarktiki i Mirovogo okeana [Studies in the Arctic, Antarctic and world oceans]. Leningrad, Gidrometeoizdat: 140-149

Quenouille MH 1952 Associated measurements. London, Butterworths

Semtner A J Jr In press The climatic response of the Arctic Ocean to Soviet river diversions. Climatic Change

Shpaykher A 0, Fedorova Z P 1976 Krupnomasshtabnyye kolebaniya solenosti morey sibirskogo shel'fa [Macroscale variability of salinity in the seas of the Siberian shelf]. Trudy Arkticheskogo i Antarkticheskogo Nauchno-Issledovatel'skogo Instituta 319: 42-62

Shpaykher A O, Fedorova Z P, Yankina Z S 1972 Mezhgodovyye kolebaniya gidrologicheskogo rezhima morey sibirskogo shel' fa kak reakts iya na atmosfernyye protsessy [Interannual variations in the hydrological regime of the Siberian sea-shelf in response to atmospheric processes]. Trudy Arkticheskogo $i$ Antarkticheskogo Nauchno-Issledovatel'skogo Instituta 306: 5-17 
Stigebrandt A 1981 A model for the thickness and salinity of the upper layer in the Arctic Ocean and the relationship between the ice thickness and some external parameters. Journal of Physical Oceanography 11(10): 1407-1422

Timofeyev V T 1962 Vl iyaniye glubinnykh atlanticheskikh vod na obrazovaniye i tayaniye 1 'da $v$ moryakh Karskom $i$ Laptevykh [The influence of deep Atlantic water on the formation and melting of ice in the Kara and Laptev seas ]. Okeanologiya 2(2): 219-225 UNESCO 1966-1979 Discharge of selected rivers of the world. 3 vols. Paris, UNESCO

Walsh J E 1979 A data set on northern hemisphere sea ice extent 1953-76. Glaciological Data Report GD-2: $49-51$ 